\title{
Terrorismo e os atentados de 11 de setembro
}

\author{
SALY DA SILVA WELLAUSEN
}

RESUMO: O fenômeno da fragmentação mundial produziu uma nova ordem nas relações de poder, estabelecendo uma nova tensão entre os de "cima" contra os de "baixo", verticalizando o antigo eixo geopolítico leste/oeste da Guerra Fria. Os elementos formadores das identidades oprimidas aspiram à afirmação de um modo de ser, constituindo o caráter ontológico da personalidade coletiva. Percorrer as razões teóricas que alimentam o pensamento e a ação terrorista, suas estratégias e táticas discursivas, é o objetivo desse trabaIho. Uma ontologia da violência brota do interior dos conceitos foucaultianos microfísica, biopoder, sujeito, liberdade, jogos de verdade, cinismo -, destruindo tudo com seu poder avassalador. Na nova ordem mundial, o terrorismo enquanto ação pontual é o contraponto ao poder dominante, como presença ameaçadora e difusa, agindo pela surpresa, disseminando medo e destruição por onde passa.

\section{Introdução}

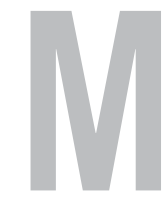

ichel Foucault propõe uma leitura crítica da razão ocidental, quando enfatiza duas dimensões: de um lado, o senso cartesiano que constitui a fundação do tipo legal da razão; de outro, seu senso contemporâneo, o do biopoder e da disciplina. Ao dar ênfase ao segundo senso, essa leitura garantia uma certa relação entre teoria e prática; a teoria - purificada do totalitarismo, arbítrio e despotismo - pode propor, legitimamente, um estudo do menor suporte da ordem

PALAVRAS-CHAVE:

violência, terrorismo, poder, biopoder, cinismo, racismo, 11 de setembro de 2001.
Professora do Departamento de Filosofia da FFLE - Universidade Mackenzie 
Esse trabalho foi apresentado originalmente no Congresso Internacional Local Practices and the Concern for Truth, Ethics, Policy(ies) and Epistemology in the Social Sciences, intitulado "Terrorismo e violência", realizado na Ilha de Egina na Grécia, de 17 a 19 de maio de 1997. O presente texto foi atualizado em vista dos atentados aos Estados Unidos. social, do grau que não derivaria de "cima", mas que poderia emanar de "baixo", e perguntar como este "baixo" se formou no interior do contexto das relações de poder, dentro de um ramo de conhecimento e intervenção política. Em outras palavras, essa leitura de Michel Foucault tem feito parte de uma reformulação de hipóteses das ciências sociais, garantindolhe um importante baluarte ou álibi.

O final do século XX testemunhou um fenômeno que está avançando: a fragmentação social. Esse fato coincide com processos no interior dos quais problemas de preservação social ou estado de bem-estar é o ponto focal. A saída é perguntar em que dimensão e sob quais condições existe coincidência do social e do objeto político-governamental. Trata-se de um evento que permanece no interior do tecido social, com enfoques sociológicos e filosóficos. No interior da realidade da fragmentação social, observa-se a ascensão das práticas locais e sua relação com a verdade. O nascimento de novos problemas levanta suposições a respeito de sua natureza e conseqüências.

Michel Foucault assinalou a distinção da singularidade e da autonomia nas práticas locais como um necessário e desejável desenvolvimento, mas também capaz de nos desviar da filosofia que, em primeiro lugar, foi reconhecida e designada de "cima", uma tradição filosófica e “co-responsável” pelas provas e atribulações, catástrofes e totalitarismos nos últimos séculos.

Várias abordagens podem ser feitas na análise do tipo de relação entre as práticas e o discurso das ciências sociais com o "outro", que poderia estar "acima" ou "abaixo", entendendo-se essa verticalização da relação como uma nova geopolítica: 1) abordagem romântica que invoca a imaginação ao estabelecer novos pontos de contato com ela; 2) abordagem liberal que desmente a possibilidade e o desejo para uma relação totalitária, ao procurar a postulação de regras básicas para a coexistência pacífica de múltiplas “outras” práticas; 3) abordagem funcional-utilitária (como inibições e "as angústias da consciência") que reconhece o papel participante para as ciências sociais no pós-estruturalismo de uma "metafísica" mínima requerida para o gerenciamento social.

O estudo daqueles que estão em "baixo", no interior das relações de poder e no domínio do saber e intervenção social, chama a atenção de estudiosos. A fragmentação do tecido social propicia o aparecimento de relações de forças, em que os em "baixo" adquirem um poder inusitado. Dentro desse contexto, os atos terroristas são fenômenos que eclodem como algo externamente violento, em que a ação de grupos impressiona pelo poder devastador.

Não é objetivo desse trabalho fazer um relato minucioso dos atentados terroristas; trata-se mais de levantar algumas hipóteses de natureza teórica a respeito de seus traços principais, suas características, dinâmica, a partir de algumas indicações sugeridas por Michel Foucault 
nas últimas lições proferidas no Collège de France, em 1984 (cf. Foucault, 1991b). Serão comentadas algumas ações terroristas mais significativas para pontuar suas estratégicas e táticas. E após 11 de setembro de 2001, é imprescindível analisar os ataques terroristas aos Estados Unidos.

Como suporte teórico, é necessário fazer uma reflexão da concepção de poder (e biopoder), do conceito de sujeito e liberdade, dos "jogos de verdade" e da Razão Cínica no pensamento de Michel Foucault. O estudo da trans-historicidade da Razão Cínica permite adentrar no conceito de terrorismo, sem envolver juízos de valor. O conceito de microfísica do poder é um pressuposto teórico importante para explicar o surgimento do terrorismo, possibilitando entender o poder, não mais localizado no interior de estruturas do Estado, mas disseminado no interior do tecido social. A análise dos “jogos de verdade”, nos quais a questão da verdade/ falsidade faz parte de um processo imanente entre poder e saber, são temas propostos por Foucault nos anos 80 (cf. Wellausen, 1993). Percorrer as razões teóricas que alimentam o pensamento e a ação terrorista, seus mecanismos de poder, suas estratégias e suas táticas discursivas é buscar os caminhos que levam à ontologia dessa prática de violência, abrindo um espaço para o aparecimento de uma nova forma de sujeito que povoa nosso cotidiano, surpreendendo-nos com atentados nos mais diversos lugares do planeta.

\section{Geopolítica e fragmentação}

Após a desagregação dos blocos geopolíticos, formados com a Segunda Guerra Mundial e a Guerra Fria, em conjugação com o desenvolvimento intensivo e extensivo do capitalismo no mundo, observa-se a emergência da questão nacional. Nos anos 90, o mundo viu o nascimento de um mundo "plural”, com o desaparecimento do comunismo do cenário ocidental, marcando a transição histórica da geopolítica ocorrida na segunda metade do século XX, determinada pela rivalidade ideológica entre as duas potências mundiais. De um lado, o socialismo nasceu como programa em 1848, com o Manifesto Comunista de Karl Marx. O comunismo assumiu o poder na Rússia em 1917, estendeu-se ao Leste europeu no pós-guerra e findou, simbolicamente, em 9 de novembro de $1989 \mathrm{com}$ a queda do Muro de Berlim. No Extremo Oriente, na China, a doutrina marxista influenciou poderosamente a vitória de Mao Tse-Tung na luta contra Chiang-Kai-Shek, estabelecendo novo regime comunista a partir de 1949, e que é até hoje a grande expressão do socialismo. De outro lado, o capitalismo moderno nasceu da Revolução Industrial Britânica no século XVIII e da Revolução Francesa em 1789. O fim dos blocos geopolíticos, desenvolvendo o conteúdo puramente geográfico aos conceitos "leste" e "oeste", criou condições para o surgimento de um mundo multipolar. 
Ao lado do processo de quebra de barreiras no mundo, desenvolve-se o fenômeno da fragmentação, em que tensões e conflitos entre setores sociais dominantes e setores subalternos realimentaram as mais diversas manifestações de intolerância e opressão. Dentre os inúmeros casos observados, o povo curdo, por exemplo, que forma a quarta maior nacionalidade do Oriente Médio, continua oprimido e perseguido, sofrendo contínuas operações de violência por parte de governos, aos quais se encontram submetidos; na última década do século XX, os curdos continuaram a lutar pela autodeterminação, sem êxito. $\mathrm{O}$ que ocorreu neste período é o reflexo do ocorrido no passado. Problemas como esses são sempre mesclados com problemas sociais, econômicos, políticos e culturais.

O fim da Guerra Fria reabriu lutas étnicas, em que questões regionais e locais substituíram blocos mundiais na relação entre países. Do enclave armênio, da Ásia Central aos países bálticos, do Kosovo iugoslavo à Transilvânia romena, da Moldávia à Bulgária surgiram tipos de reivindicações etno-regionais, evidenciando, cada uma à sua maneira identidades coletivas em busca de sua autonomia. As mutações da sociedade civil caminharam lado a lado com as tentativas de reorganizar seu espaço geopolítico: Hungria e Romênia deterioraram suas relações; graves tensões abalaram Albânia e Iugoslávia; sangrentos combates ocorreram entre armênios e azerbaijanos, enquanto um acordo de paz entrou em vigor em Angola e na Namíbia, em 1988. No Terceiro Mundo, a queda dos blocos acarretou o recrudescimento de conflitos etno-regionais: o conflito norte-sul no Sudão, a guerra da Eritréia, as disputas no interior do Paquistão, as matanças inter e intra-religiosas no Líbano. Como desideologização das relações entre as grandes potências, esse fenômeno promoveu novas formas de clientelismo internacional. A revalorização da etnicidade, enquanto recurso político, regeu esse fenômeno: as ideologias "fracas", centradas sobre o jogo das afinidades culturais e históricas, recusaram a forte ideologia das rivalidades entre Leste e Oeste. "Quando se debilitam os estados nacionais preexistentes, logo ocorre a ressurgência de nações e nacionalismos, religiões e línguas, territórios e geografias, histórias e tradições, identidades e fundamentalismos, etnicismos e racismos" (cf. Ianni, 1996, p.12). Sob diversas formas, a etnicidade desempenhou o papel de uma moeda de troca, cujo valor simbólico ou estratégico dependeu da conjuntura e do contexto onde ela circulou. Quando o exército da Etiópia sofreu graves derrotas militares na Eritréia, as autoridades de Adis Abeba não hesitaram em trocar o "direito de saída" dos judeus falashas por armas vindas de Israel. No Chade, a retirada do apoio líbio à dissidência "árabe" é entendida por Muamar Gadafi como um compromisso necessário com vistas a uma ordenação do grupo de Aouzou e como um primeiro passo para a libertação dos líbios capturados nos campos de batalha de Burku. A União Soviética tentou enfrentar um outro 
tipo de negociação para manter as irredutíveis pressões separatistas dos ucranianos, bálticos, moldovos, azerbaijanos, armênios, georgianos e russos, isto sem falar das minorias étnicas enraizadas no interior de cada uma dessas nacionalidades. A etnicidade não foi apenas um recurso negociável, muitas minorias, na Europa e em todo mundo, foram tratadas como simples bodes expiatórios, quando não usadas como pretexto para ingerências assassinas na vida política dos Estados: o eterno problema palestino, a destruição do Líbano pelas intervenções israelenses e sírias, os conflitos no Sri Lanka. Através dos massacres, uma nova lógica do conflito tendeu a se impor aos protagonistas em favor das ingerências vindas de fora. Os espaços geopolíticos do Terceiro Mundo delinearamse por crises, cuja intensidade dependeu do ritmo de crescimento das desigualdades entre etnias e regiões, contaminando as relações entre Estados (cf. World Media, 1990).

As relações de poder que se bipolarizaram, depois dos anos 90, disseminaram-se no interior do planeta, com o aparecimento de novos focos de poder. Minorias esmagadas e massacradas pelos Estados ocupam um novo espaço, dando lugar à emergência de novas estratégias expressivas de velhas relações de poder. A história oferece um campo de possibilidades para a emergência dos que não detém o poder, mas que podem irromper no seio da sociedade e se fazerem ouvir. O deslocamento de velhas relações de poder se encaminha para uma nova maneira de resolver antigas tensões. Nesse novo espaço, o terrorismo vai mostrar sua fisionomia, como uma forma surpreendente de utilizar a violência.

Se a polaridade política, em meados do século XX, definiu horizontalmente as relações de poder entre leste e oeste, como "direita" e "esquerda", no final do século, particularmente nos anos 90, essa denominação tomou outra direção, verticalizando as relações de poder entre os de "cima" e os de "baixo". Ao mesmo tempo em que a escala de economia e administração de negócios fica mais ampla, existe a tendência psicológica de se olhar para algumas coisas com as quais se possa identificar, se reconhecer, no vasto mar do anonimato. A busca pela identidade é a afirmação de um modo de ser, mobilizando relações e elementos culturais, formas de agir, sentir e pensar alheios, com os quais se busca afirmar ou imaginar a identidade individual ou coletiva. Aqueles que estão fechados dentro de um grupo, religião ou nação, tendem a imaginar que sua própria maneira de viver, de pensar, de ver o mundo, tem validade absoluta e imutável.

A fragmentação histórica gera sectarismos e fanatismos, contribuindo para a formação de identidades grupais e coincidindo com a identidade de grupos oprimidos. É nessa busca que essa consciência-emsi está sujeita a transforma-se em consciência para si. Os elementos formadores das identidades oprimidas, enquanto características reais ou imaginárias, aspiram à afirmação de um modo de ser, constituindo o ca- 
ráter ontológico da personalidade coletiva, revestida de uma linguagem comum introjetada pelo grupo que permite delimitar, localizar, classificar as diversidades e oposições constitutivas da dinâmica da realidade social e histórica. É esse caráter ontológico da personalidade terrorista, seja individual ou grupal, que nos interessa estudar.

\section{Exterminação e terrorismo}

A história registra a presença da violência em suas formas mais extremas: guerra, massacre, genocídio, extermínio, terrorismo. A guerra ressalta de uma violência institucionalizada, ritualizada, e por mais cruel que seja, admite regras e leis que engendram a beligerância e supõe a busca da paz; reconhece o inimigo como pessoa, respeita os feridos e prisioneiros, poupa as populações civis. Essa prática ideal é negada pelo massacre, pelo desencadear selvagem do ódio e das pulsões destrutivas: abandono de feridos, matança de prisioneiros, tortura, violação, mutilações, queima, execução de mulheres, crianças e velhos. Através de destruições deliberadas, sistemáticas e programadas, o genocídio atinge o auge do horror na eliminação total de indivíduos. O terrorismo age de forma contrária ao extermínio. Enquanto este tem produzido massacres e genocídios no curso da história, no interior da qual Estados, identificados em torno de um projeto ou de uma crença, lançam-se sobre seus semelhantes (percebidos como diferentes) para matá-los em massa, abrangendo quantitativamente o maior número de indivíduos, o terrorismo pretende exercer uma violência qualitativa, com métodos econômicos, quase cirúrgicos.

A prática de exterminação estalinista é extensiva: todos, sem excluir ninguém e de forma igualitária, são bons para o gulag; os massacres realizam-se durante um tempo indefinido, espalhando milhões de vítimas pelos vastos territórios siberianos, que vão morrendo aos poucos. A prática nazista tem um ritmo mais intensivo, agindo rápido, liquidando os grupos humanos de forma mais seletiva, em espaços limitados ou fechados, em campos de concentração, câmaras de gás, caminhões asfixiantes, guetos e empilhamento de cadáveres em valas comuns (cf. Dadoun, 1993). É também uma forma de violência de Estado a estratégia praticada pelos americanos - o lançamento das bombas atômicas nas cidades japonesas de Hiroshima e Nagasaki, na Segunda Guerra Mundial. A guerra na Europa já havia sido definida desde 8 de maio de 1945, com a rendição dos alemães e seus aliados. Na mesma época, na frente do extremo oriente, a guerra continuava contra o Japão, tendo este perdido suas principais ilhas de apoio e de defesa (desde 1944), sofrendo constantes ataques e bombardeios em seus principais centros industriais. Em fins de julho de 45 a rendição das forças japonesas era iminente, quando o estado maior nipônico discutiu com o imperador as condições e termos da rendição. A 
guerra já havia sido vencida pelos americanos, mas os EUA resolveram, "para apressar o fim da luta e poupar seus exércitos", lançar em 6 de agosto de 1945 a primeira bomba atômica sobre Hiroshima e três dias depois a segunda bomba sobre Nagasaki, exterminando instantaneamente mais de 200.000 pessoas, na maioria, velhos, crianças e mulheres.

O êxito do ato terrorista, enquanto violência qualitativa, reside nas estratégias da ação pontual: o "atentado" concentra-se num ponto limitado no tempo e no espaço, apanhando de surpresa a multidão anônima e passante, e que pode ser praticado pelos indivíduos dessa mesma população (cf. Dadoun, 1993). "A principal característica desse terrorismo é que ele ataca, sobretudo, os civis. Eles querem o maior número de mortos e a maior visibilidade possível. É muito difícil se proteger desse tipo de ataque" (cf. Maxwell, 2001, p. 19).

Para Norberto Bobbio, o terrorismo, como recurso comum à violência, distingue situações diversas, conforme seu peso político. Tanto pode ser um instrumento de governo para se manter no poder, quanto instrumento de libertação nacional em nações dominadas; de uma forma ou de outra, o terrorismo é sempre a quebra da ordem imposta pelo poder dominante. A palavra terror entrou na política em 1792, com a Revolução Francesa: em dois anos foram sumariamente guilhotinados, em Paris, 1.300 supostos adversários do novo regime. É ainda consensual que o terrorismo tenha nascido entre os anarquistas russos que, em 1881, mataram o czar Alexandre II. O ato terrorista de maior amplitude ocorreu em 1914, quando um ativista sérvio matou, em Sarajevo, o arquiduque Francisco Ferdinando, herdeiro do trono da Áustria, sendo o estopim da $1^{\mathrm{a}}$ Guerra Mundial.

O terrorismo, enquanto prática pontual, é expressão da necessidade de afirmação política. Alguns grupos, no combate militar mais amplo, conseguiram chegar ao poder: na África do Sul, Nelson Mandela, de terrorista durante o Apartheid, chegou a presidente em 1994 e depois a Nobel da Paz; Iasser Arafat também recebeu o mesmo Nobel, mesmo sendo terrorista no passado, quando era dirigente da OLP. Israel e os norte-americanos são alvos preferenciais de atentados, estes últimos, não só pela política pró-Israel no Oriente Médio, mas porque o terrorismo islâmico se opõe à modernização dos costumes estimulada pela globalização (cf. Natali, 2001). É comum a mídia falar de terrorismo de Estado, e neste caso trata-se do processo de exterminação, de matança extensiva: durante a Guerra Fria, é atribuída não só à ex-União Soviética, como aos Estados Unidos uma profusão de atentados. Irã, Síria, Líbia e Iraque seguiram os mesmos passos. Trata-se, no fundo, de um Estado que pode mandar matar e financiar grupos clandestinos para realizar extermínios em massa. E foi justamente na guerra do Afeganistão contra os soviéticos que os EUA prepararam e financiaram o grupo de Osama Bin Laden (como também foram os EUA que financiaram e contrataram Saddam 
Hussein para atacar o Irã).

Os Estados poderosos detêm a hegemonia do princípio estratégico: "poder matar para poder viver". Se o genocídio é de fato o sonho dos poderes modernos, é porque o poder se situa e se exerce no nível da vida, da raça, dos fenômenos maciços de população, como biopoder. Nas relações entre exterminação e terrorismo pontual existe uma assimetria que escapa à lógica das guerras tradicionais. Antes de ser causa da violência, os terroristas se percebem e se designam como produto de uma violência antecedente: dominação política, colonial, exploração econômica, opressão social, etc. Sempre uma violência anterior legitima uma violência ulterior (cf. Dadoun, 1993). Para o pensamento terrorista, o inimigo é o outro, aquele que detém um poder maior que o seu no uso de práticas de extermínio. Como é estrategicamente inferior, o terrorismo precisa combater o poder maior através do ataque pontual, pela surpresa e pelo inesperado. A natureza dos ataques montados com base em funções regulares da sociedade significa que não existe defesa abrangente ou conclusiva.

\section{Racismo}

Foucault aborda a questão do Estado a partir da noção de "razão de Estado" e da racionalidade liberal de governar, reelaborando a noção de poder através do conceito de "governo", como a maneira de conduzir a conduta dos outros. O tema do nascimento do racismo de Estado encontra sua origem na teoria clássica da soberania: o poder tomou o homem enquanto ser vivo, estatizando o biológico. Do ponto de vista da vida e da morte, o sujeito é neutro e seu direito de viver e de morrer decorre da vontade do soberano. Esse paradoxo teórico completa-se com um desequilíbrio de ordem prática. O efeito do poder do soberano sobre a vida exerce-se no momento em que o soberano pode matar - "é o direito de matar que detém efetivamente a essência desse direito de vida e de morte; é no momento em que o soberano pode matar, que ele exerce seu direito sobre a vida [...] é o direito de fazer morrer e deixar viver" (cf. Foucault, 1991a, p. 38).

O racismo nos Estados modernos, após a Revolução Francesa e início do século XIX, é introduzido no domínio da vida gerido pelo poder - o biopoder, preconizando uma ruptura entre aquele que deve viver e o que deve morrer. Se, de um lado, o biopoder reivindica a vida, como sede das necessidades fundamentais, a vida passa a ser a essência fundamental do homem: "direito" à vida, ao corpo, à saúde, à felicidade; por outro, o velho direito soberano de decidir a morte permanece fundamental, não se tratando de uma morte direta, mas de tudo aquilo que possa efetivamente causar uma morte, expor à morte, multiplicar os riscos de morte - morte política, expulsão, exclusão de elementos à margem da sociedade. Ao 
Estado é dada a competência de gerir a população, porque produz o indivíduo. Ao lado desse poder-saber, a reafirmação das prerrogativas do direito soberano de decidir a morte permanece inalterável.

A teoria racista moderna visualiza dois campos no interior da sociedade e que se repartem entre "fazer viver" e "fazer morrer": de um lado, uma ruptura do discurso científico; de outro, a importância da atuação da norma que uniu a lei ao gládio, e sua arma por excelência é a morte, situada num domínio de utilidade. A raça é o lugar do exercício do biopoder, estabelecendo uma relação de tipo guerreiro: "para viver é preciso massacrar os inimigos"; uma relação, não mais de enfrentamento militar, mas de natureza biológica "se queres viver é preciso que outro morra" - a eliminação do perigo biológico reforça a própria espécie ou raça. A partilha entre normal e patológico estabelece uma hierarquia das raças em superiores e inferiores, desaparecendo a coexistência de suas diferenças. Povos subordinados são dessa maneira concebidos (pelo menos implicitamente) como outro ser não humano, como uma diferente ordem de ser. As teorias racistas modernas fundadas na biologia implicam numa diferença ontológica, que se inclina na direção de uma ruptura necessária, eterna e imutável na ordem do ser.

O racismo realiza um corte de tipo biológico, permitindo que se possa visualizar a população como mistura e fragmentação de raças. Conforme Octávio Ianni, etnia e raça são conceitos científicos. O primeiro é utilizado para distinguir os indivíduos ou as coletividades por suas características fenotípicas; o segundo designa indivíduos, grupos ou coletividades que se definem e se reconhecem reciprocamente como pertencentes a raças distintas. A raça é um conceito cultural que gera intolerâncias, discriminações, segregações ou ideologias raciais. Os racismos com forte dose de darwinismo social separam os indivíduos a partir de interpretações mágicas, elegendo o euroculturalismo, a ocidentalidade, o arianismo, a civilização judaico-cristã ou o capitalismo como parâmetros da história universal (cf. Ianni,1996).

$\mathrm{O}$ anti-racismo moderno se posiciona contra o essencialismo biológico, e insiste em que as diferenças entre raças são constituídas, com maior certeza, por forças sociais e culturais. Um apelo à igualdade entre os seres humanos parece emanar desse construtivismo social que nos livrará do determinismo biológico. Na passagem do racismo biológico para o cultural, as diferenças biológicas são substituídas por vetores culturais, como representação mais importante do ódio e do medo raciais (cf. Hardt \& Negri, 2001).

A teoria racista pós-moderna afirma que as raças não constituem unidades biológicas isoláveis e que a natureza não pode ser dividida em raças humanas. As diferenças são efeitos contingentes da história social. É a partir desse argumento relativista e culturalista que a ideologia dominante de nossa sociedade pode parecer anti-racista ou não-racista. 
No entanto, esse novo racismo diferencialista exige rígidos limites de flexibilidade e compatibilidade de culturas: é inútil e até perigoso que culturas se misturem. As diferenças raciais são contingentes em princípio, mas necessárias na prática como marcadoras de separação social. A teoria pós-moderna é uma teoria de segregação social: a hierarquia racial é vista não como causa, mas como efeito de circunstâncias sociais e históricas; é determinada a posteriori, surgindo da livre competição entre culturas, com as leis de mercado. Esse racismo opera pela determinação de graus de desvio em relação ao padrão ariano. Não há exclusão pelo tipo racial e cultural (uma vez que todas as culturas são teoricamente iguais) e nenhuma identidade é designada como o Outro, não existe lado de fora, o Diverso. O racismo pós-moderno funciona, primeiro, atraindo a alteridade e depois subordinando as diferenças de acordo com o grau de desvio do padrão de homem branco. O ódio nasce das práticas de controle, da proximidade e desenvolvimento com base nos graus de diferença do próximo. Como a alteridade não chega ao exercício da Diversidade, a questão da exclusão racial é resultado da inclusão diferenciada. A subordinação é realizada em práticas diárias, móveis e flexíveis que chegam a criar hierarquias raciais estáveis e brutais. Um povo sempre foi definido em termos de lugar, de um território. O raciocínio racista pós-moderno não opera com essa dialética, sua lógica é outra. Noções fixas e biológicas de povos tendem a se dissolver numa multidão fluida e amorfa, passando por linhas de conflito e antagonismo e nada se constitui como fronteira fixa e eterna. A superfície da sociedade pós-moderna, ou globalizada, muda continuamente desestabilizando qualquer noção de lugar. Não há antítese entre interior e exterior. $\mathrm{O}$ racismo diferenciado integra uns e outros à sua ordem e estabelece essas diferenças num sistema de controle. O racismo do século XXI repousa nesse jogo de diferenças e na administração de microconflitos dentro de seu domínio em contínua expansão. A exclusão racial necessita integrar a inclusão diferenciada para apagar as fronteiras territoriais e para que o exercício e a expansão do poder possam se efetivar como controle e dominação (cf. Hardt \& Negri, 2001).

\section{A microfísica do poder}

Para se entender as relações de forças inscritas no ato terrorista, é preciso fazer a análise do conceito de poder no pensamento de Foucault. O poder é deslocado dos conceitos clássicos da ciência política. As condições de possibilidade do poder não devem ser procuradas num foco de soberania, numa instância a priori, mas nos relevos, nas dobras ínfimas de uma hierarquia, controle, vigilância, proibição ou coação. Em todo lugar onde há poder, o poder se exerce. Nada é seu titular e, no entanto, ele se exerce em determinada direção. Pode-se não saber quem tem o poder, mas sabe-se seguramente quem não o possui. O poder consiste 
numa multiplicidade de relações de forças imanentes e próprias do domínio em que se exercem e que são constitutivas de sua organização. É um marco global de complexas relações de forças. Compreender o poder é buscar a gigantesca rede de relações e "discursos" aceitos como verdadeiros e que constroem e destroem os visíveis e transitórios pontos de soberania. Em vista disso, ver o poder como aparelho de Estado, modo de vigilância na forma de regra, sistema de dominação exercida por um elemento ou grupo sobre outros - e cujos efeitos atravessariam o corpo social por inteiro - é contemplar as suas formas terminais.

$\mathrm{O}$ poder produz o saber e a verdade. O poder e o saber são imanentes, no sentido em que o efeito permanece no interior de sua causa, sem almejar um fim transcendente ou exterior. São os "jogos de verdade" que mostram como poder e saber se articulam no interior do "discurso". Os discursos são elementos ou blocos táticos num campo de relações de forças. O poder é uma carta estratégica que tem blocos táticos, os discursos. A analítica do poder mostra que os poderes não são eternos e nem os saberes imutáveis, mas encontram-se na espacialidade da pura atualidade, inscrevendo-se num campo de possibilidades esparsas e se apoiando em estruturas permanentes. O poder é a maneira pela qual sujeitos ativos agem sobre outros sujeitos, também ativos, gerando a resistência dos mil poderezinhos, no choque pontual situado nas instâncias mais disseminadas do tecido social. A estratégia das minorias terroristas utiliza o elemento "surpresa" como algo novo diante de um poder superior. É a microfísica do poder deslocando o poder de um centro gerador, disseminando e fragmentando as relações de poder. Nessa microfísica do poder, uma violência anterior é o pressuposto que legitima a ação terrorista dos de "baixo" e assegura ao grupo fortes laços de envolvimento. De uma maneira geral, a violência se expressa de duas maneiras: primeiro, no "interior" do próprio grupo terrorista - violência interna, densa, nodal - e que encontra seu fim no brilho estilhaçante do ato praticado; segundo, o atentado dirige-se para o "exterior" e se desdobra em ondas de violência em toda sociedade, irradiando-se no interior da população, no espaço público, como violência nebulosa e surda, que excede, transborda e ultrapassa os limites, as fronteiras. Enquanto estratégia de um poder onipresente e difuso, o terrorismo age por amostragem, uma vez que não é preciso destruir "toda" a sociedade para alcançar o fim proposto, basta atingir uma parte, um ponto qualquer para estabelecer o medo, o pânico e o horror (cf. Foucault, 1991c).

\section{O perfil do terrorista}

Uma questão que se coloca é perguntar pela possibilidade de se definir uma personalidade terrorista. Quais os traços comuns dos agentes que aplicam métodos tão diversificados? Relacionando o grupo terrorista 
com os indivíduos que dele fazem parte, é possível dizer que a identidade dos indivíduos se deriva da identidade que o grupo constrói para si mesmo. O Grupo, interiorizando o princípio mesmo do terror, é erigido em entidade superior e ideal. Centrado sobre si mesmo, egocêntrico e narcisista, o Grupo pretende alcançar autonomia e identidade, como matriz do discurso, do valor dinâmico, da coerência e da justificativa do atentado. Cada indivíduo vai buscar no Grupo uma nova identidade que lhe dá sentido, como uma verdade a ser assumida e proclamada: "Meu nome é Terror!" Essa redução da personalidade é modelada por regras e palavras-de-ordem. As organizações exigem que o revolucionário não tenha interesses pessoais, propriedades, nem sentimentos ou laços afetivos, família, nem mesmo nome. Tudo nele deve se resumir a um só pensamento, uma só paixão - a Revolução! O objetivo maior é formar quadrilhas com uma força única e invencível (cf. Dadoun, 1993). Para integrar plenamente o grupo, o aderente deve cometer um crime ou um ato semelhante, como prova ou rito de iniciação. Um pacto de sangue une os membros de um grupo, tornados "iniciados", com todas as conotações religiosas, mágicas, sectárias que o termo veicula. O grupo está atravessado, permanentemente, por múltiplas relações de força e de dominação e, ao mesmo tempo, por fortes laços de solidariedade coercitiva. Relações tensas e conflituosas - camufladas por considerações táticas ou ideológicas - alimentam os movimentos terroristas: tomadas de poder, acertos de contas, traições reais ou imaginárias, execuções sumárias, dissidências, suicídios. $O$ grupo constitui um meio privilegiado para o aparecimento de idéias persecutórias, delírios missionários, visões apocalípticas, misticismos de toda espécie; entidade autônoma, errante e excluída do corpo social, no entanto, o grupo se autoproclama "popular". Paradoxo que irrompe na realidade social: por um lado, condenação e desprezo social; por outro, valorização que encobre um projeto "revolucionário" que o ato terrorista torna público e arbitrário. Essas forças conflituosas são suficientes para cimentar o grupo e assegurar homogeneidade e densidade, de forma que o grupo terrorista se constitui como uma "célula" autárquica, um "núcleo" resistente, uma "facção". Alguns grupos assim se autodenominam: Núcleos Armados para a Autonomia Popular, Células Comunistas Combatentes, Facção do Exército Vermelho, além de outros (cf. Dadoun, 1993).

Se há nos terroristas um elemento de loucura, nem todos paranóicos são terroristas, mas a maioria dos terroristas acredita numa conspiração global gigantesca de um inimigo todo-poderoso, satânico, que há de ser destruído. Taheri afirma que as organizações terroristas muçulmanas podem ser divididas em três categorias: 1) grupos que são controlados em parte por algum Estado - o Hezbollah; 2) terroristas que se concentram em questões específicas e ações locais - organizações palestinas contra israelenses e outras dúzias de grupos parecidos e ativos em partes da África - de Zanzibar à 
Nigéria; 3) grupos terroristas pan-islâmicos que fazem a guerra global contra “os inimigos do Islã”, reais ou imaginários (cf. Taheri, 2001, p. 72-73).

Mas, na história do terrorismo moderno, nenhum atentado alcançou tamanha magnitude como o do grupo pan-islâmico Al Qaeda (A Base). Criado no final dos anos 1980 por Osama Bin Laden (com o objetivo de reunir os árabes que haviam ajudado os afegãos a derrotar os soviéticos), a intenção do grupo era criar um califado pan-islâmico no mundo e expulsar os ocidentais dos países muçulmanos. Em fevereiro de 1998, o grupo lançou um decreto religioso (fatwa), segundo o qual os muçulmanos deviam matar norte-americanos e seus aliados. O grupo é acusado de ter dirigido os ataques ao World Trade Center e ao Pentágono, no dia 11 de setembro de 2001, "quando morreram 2.819 pessoas" (cf. D’Ávila, 2002). Em agosto de 1998, fez os atentados a bomba contra as embaixadas dos Estados Unidos no Quênia e na Tanzânia, deixando um saldo de 301 mortos.

Contudo, nem todos os atos terroristas têm caráter religioso. Existem grupos que são eminentemente políticos. Originados nos anos 1960, o ETA (Pátria Basca e Liberdade) prega a criação de um Estado basco no norte da Espanha e no sudoeste da França, e o IRA (Exército Republicano Irlandês) defende a saída das forças britânicas da Irlanda do Norte. O primeiro já matou mais de 800 pessoas, através de atentados a bomba, cujos alvos prediletos são militares, políticos e juízes espanhóis; o segundo praticou centenas de atentados a bomba, seqüestros, extorsões e assassinatos, em estações de metrô e centros comerciais na Inglaterra.

\section{Estratégias terroristas e mídia}

O terrorismo e o anarquismo foram citados por Foucault nos Cursos do Collège de France, por volta de 1983/1984, e operam no campo das lutas políticas. Tanto um como o outro se caracterizam como forma de ação política no combate ao poder estabelecido. Se, por um lado, o anarquismo é uma teoria política segundo a qual as formas de governo interferem injustamente na liberdade individual, preconizando a substituição do Estado pela cooperação de grupos associados e incitando a resistência a toda ordem estabelecida; por outro, o terrorismo combate o poder vigente mediante o emprego da coação na forma da extrema violência e do uso sistemático do terror. Com relação ao poder a que se opõem, enquanto o anarquista, portador de um discurso libertário incita à desordem, à sublevação, o terrorista utiliza instrumentos de extermínio. O discurso anarquista tem um opositor visível, o Estado - o contraponto que dá sentido à sua ação. Os atos terroristas não se dirigem diretamente ao poder mais forte, os de "cima"; eles procuram atingir uma parte da sociedade, para alcançar o todo. Dessa forma, o terrorismo age por amostragem - basta atingir um ponto para estabelecer o medo, o terror. 
No pensamento de Michel Foucault, a ação pontual é explicável pelas categorias do poder, que são determinações próprias a ações consideradas como "quaisquer" e a um suporte qualquer - o atentado é o poder de causar a morte a uma multiplicidade qualquer, desde que não seja numerosa. É a prática do panoptismo inserida na modernidade desde o final do século XVIII (cf. Foucault, 1991b).

O que dá suporte à eficácia do terrorismo é a noção moderna de "soberania", pensada como soberania dos cidadãos em substituição à soberania do Rei: a relação Rei-súdito se desloca para o espaço público, transferindo o poder supremo centralizado na figura do Rei para a sociedade civil. Se um crime é praticado contra alguém, a sociedade inteira sente-se lesada e acha-se no direito de exigir a punição do criminoso. E, inversamente, dentro dessa lógica que habita o imaginário popular, a ação terrorista procura atingir uma parte da sociedade para atingir a soberania do todo.

Estratégias e táticas de poder estão desvinculadas no ato terrorista. Enquanto a ação terrorista escolhe, aleatoriamente, um foco qualquer da sociedade para praticar o atentado, o discurso terrorista se endereça ao poder maior a que se opõe e isto é suficiente para mostrar a face oculta do terrorismo. A disseminação da ação terrorista implanta terror, pela estratégia do inesperado, que busca o alvo no lugar diferente daquele em que se encontra seu destinatário. A eficácia se impõe pela brutalidade da ação inesperada.

A violência terrorista atinge indiferentemente tanto personalidades do sistema como elementos anônimos no interior da multidão. A escolha de um ou de outro método depende da tendência política: o terrorismo de "esquerda" ataca indivíduos detentores do poder; o terrorismo de "direita" (terrorismo de Estado), com forte inclinação nacionalista, religiosa ou fascista, prefere desencadear um "banho de sangue". Para ilustrar estratégias terroristas de esquerda: em 1978, as Brigadas Vermelhas, de cunho comunista, raptaram o líder da Democracia cristã, Aldo Moro, retendo-o em cativeiro enquanto decorriam as negociações, para finalmente ser assassinado em condições obscuras; em 1980, um grupo neofascista coloca uma bomba na estação de Bolonha - ainda numa Itália minada pelo terrorismo mafioso. Em 1999, bombas que explodiram em Paris foram atribuídas ao Grupo Islâmico Armado (GIA).

Na franja de violências que o terrorismo carrega consigo, muitas outras linhas vêm se cruzar, suscitando imagens e julgamentos mistos de repulsa e fascinação: 1) a linha ideológica (discurso doutrinário) pretende racionalizar a violência e a linha política, onde aparecem os oportunismos; 2) a linha organizacional impele o grupo terrorista a encontrar em si mesmo seu próprio fim; 3) a linha mediadora da mass media assegura a difusão da violência no interior de todo corpo social. A televisão, particularmente, funciona como uma verdadeira caixa de ressonância, estabe- 
lecendo-se entre terrorismo e televisão uma verdadeira reciprocidade: o teleterrorismo age com predileção para a televisão e, em troca, a televisão tem o poder de propalar e irradiar os atos terroristas no instante mesmo em que são praticados. O terrorismo é mostrado em espetáculo, às vezes em ritmo de folhetim ou de novela. A partir do direito à notícia que cada telespectador reclama para si, esse direito estende-se a todos os lares e o resultado é a promoção maciça da organização, através da difusão encadeada dos medos, terrores acumulados e ameaças, a partir de um centro terrorista onipresente que alcança todos os cantos do planeta.

A mídia transforma-se em realidade mediatizada, saturada de imagens e verbosidade, no jogo entre o real e o simulacro. A realidade virtual faz o simulacro parecer mais real; a reprodução técnica do fato vivo que está acontecendo apaga a diferença entre real e imaginário, ser e aparência - o signo do real desponta como uma nova realidade, o hiperreal. As mensagens visam à espetacularização da vida, convertendo o cotidiano em um show contínuo e as pessoas em espectadores permanentes. Os espetáculos saturam o vídeo, preenchendo a função de magnificar o dia-a-dia para produzir movimento de impacto. O "incrível", o "fantástico" e o "sensacional" motivam e controlam a nebulosa de espectadores, mantendo-os continuamente à espera de novas imagens a serem consumidas (cf. Santos, 1994). Nos anos 40 do século XX, "as notícias chegavam pelo rádio, as imagens eram escassas. Hoje a mídia expõe tudo instantaneamente (...) e tudo isso provoca um impacto muito forte nas pessoas. Com relação às imagens das explosões das torres gêmeas do World Trade Center, tudo ainda se parece como um filme", afirma o historiador Kenneth Maxwell (cf. Santana Dias, 2001). Nesse jogo de manipulação, a mídia preenche sua função e realimenta o terrorismo, criando um permanente "clima de violência". Figura de extrema violência, o terrorismo se desdobra de um ponto ao outro da Terra, a partir de uma ação pontual, espalhando destruição e morte.

\section{Visibilidade e enunciabilidade}

A visibilidade do que está acontecendo no mundo, favorecida pela mídia, faz de cada telespectador "um olho que vê", faminto de novas imagens. Graças aos novos recursos, o telespectador encontra nos meios de comunicação a amplificação de seu poder de ver, de conferir a notícia - tal como no Renascimento, quando o olho humano alcançou um poder maior de observação, ultrapassando a simples experiência dos dados dos sentidos e possibilitando o avanço da ciência. A visibilidade foi largamente utilizada pelo poder institucional nas configurações de vigilância do panoptismo, do século XVII ao XIX. O panoptismo é um poder que se exerce sobre os indivíduos em forma de vigilância individual e contínua, de controle, punição e recompensa em função de certas normas. Trata-se 
de uma forma de poder, de um tipo de sociedade disciplinar que Foucault chamaria de ortopedia social. Concebido por Bentham, no século XIX, o Panopticon era um edifício em forma de anel, no meio do qual havia um pátio com uma torre no centro. $\mathrm{O}$ anel se dividia em pequenas celas que davam tanto para o interior quanto para o exterior. Em cada uma dessas pequenas celas, segundo o objetivo da instituição, havia uma criança aprendendo a escrever, um operário trabalhando, um prisioneiro se corrigindo, um louco atualizando sua loucura, etc. Na torre central havia um vigilante. Como cada cela dava ao mesmo tempo para o interior e para o exterior, o olhar do vigilante podia atravessar toda a cela, não havendo nenhum ponto de sombra - o indivíduo estava, permanentemente, exposto ao olhar do vigilante que o observava através de venezianas e de postigos semicerrados, de modo a tudo ver sem ser visto. Mesmo na ausência do vigilante, o poder é um olho que vê, perpetuamente, aberto sobre uma população, atravessando espaços, corpos e mentes. Um maior número de pessoas é oferecido como espetáculo a um só indivíduo. Esta máquina arquitetônica podia ser utilizada por uma série de instituições. $\mathrm{O}$ panoptismo vigia o tempo dos indivíduos, controla seus corpos, para serem formados, corrigidos e qualificados, em função do objetivo proposto. Poder polimorfo e polivalente que produz o indivíduo, provocando o nascimento de uma série de saberes - saber do indivíduo, da normalização, da correção e fazendo surgir as ciências do homem e o homem como objeto da ciência (cf. Foucault, 1988). O terrorismo tornou-se "um olho que vê" toda sociedade pela ação pontual de suas estratégias, como nova forma de panoptismo que torna a humanidade transparente e vulnerável.

O terrorismo opera no espaço da política, no campo das relações de força, colocando questões estudadas por Michel Foucault na analítica do poder: o poder não se centraliza mais no Estado, como núcleo originário a partir do qual emanariam os demais poderes; as instituições são formas terminais e visíveis através das quais o poder aflora e se manifesta. Foucault interessa-se mais pela análise do que permanece oculto - os dispositivos de poder-, no interior dos quais circulam novas intensidades de poder, refletindo a paisagem de cada época. Ele propõe o abandono dos postulados tradicionais atribuídos ao poder, para pensar o poder no plural, como constelação - aparecendo em alguns lugares e apresentando caráter múltiplo e dispersivo -, presente nas relações entre indivíduos e grupos, indivíduos e classes, indivíduos e instituições. De forma diferente das teorias da "guerra" (as estratégias são o planejamento e as táticas, as operações de campo), para Foucault, as táticas são os discursos no âmbito do saber e as estratégias são as ações praticadas pelos homens em diversas relações de poder.

O terrorismo não se limita apenas a estabelecer esse jogo de poder, a utilizar as estratégias sem uma correspondência tática. O que dá significado ao ato terrorista é o fato da autoria - existe sempre alguém se 
responsabilizando pelo atentado, ou presume-se quem tenha realizado o atentado pela semelhança com outras práticas terroristas. Essa questão aborda a relação entre ação e verdade inscrita no interior dos "jogos de verdade" e remete à questão das práticas locais e a verdade. Foucault descarta as concepções tradicionais de verdade, preferindo analisar as práticas discursivas, heterogêneas e historicamente condicionadas. A verdade é definida como luta, estratégia, força imanente atravessada por intensas relações de poder. A história da verdade não é uma história do saber verdadeiro, mas uma análise dos jogos do verdadeiro e do falso, através dos quais o sujeito se constitui como experiência. Os "jogos de verdade" definem-se como o conjunto de regras de produção da verdade, procedimentos que conduzem a um resultado considerado em função de seus princípios, regras de ação, válidas ou não, verdadeiras ou não. O que Foucault analisa são as eclosões concretas dos "jogos de verdade", as formas diferentes do dizer-verdadeiro. Nos “jogos de verdade", a verdade é o que se diz a partir do poder de dizê-lo (cf. Wellausen, 1993).

Dentro dessa perspectiva, o terrorismo cruza as questões da subjetividade e da verdade no interior de intensas relações de poder. A questão da autoria remete à problemática inscrita no interior dos jogos de verdade. $\mathrm{O}$ terrorismo atua como sujeito coletivo, referenciando o ato terrorista à assunção da autoria. O terrorismo constrói sua identidade a partir do ato corajoso de dizer a verdade sobre o atentado. Sua verdade reside, não só no poder de praticar a violência, como no poder de enunciar o ato praticado - identidade entre ação e autoria. Suas regras de produção da verdade são regras de ação que conduzem ao objetivo proposto, descartando todo e qualquer juízo de valor. A autoria do atentado - assumido pelo sujeito terrorista - legitima num mesmo gesto a identidade do ator terrorista e do autor enunciador do atentado. Duas vertentes brotam de um mesmo poder: a coragem de praticar o crime (estratégias de poder) e a coragem de dizer quem o consumou (tática discursiva).

Nos atentados de 11 de setembro de 2001, o grupo Al Qaeda é tanto ator quanto autor desses atentados como dos outros atentados praticados contra os EUA, e isso decorre da história amplamente documentada do terrorismo islâmico desde os anos 1980: em 1993, o primeiro atentado contra o World Trade Center; em 1998, os atentados simultâneos contra as embaixadas dos Estados Unidos no Quênia (Nairóbi) e na Tanzânia (Dar Assalaam), caracterizando a dupla coragem: de matar (estratégia) e de dizer quem matou (tática).

\section{Terrorismo e cinismo}

O terrorismo é uma vertente do cinismo, citado por Foucault (1984) no curso ministrado no Collège de France Le courage de la vérité. O cinismo, como filosofia moral, percorreu a Antigüidade para se instalar 
no interior do pensamento moderno. O cinismo foi considerado uma figura anedótica na Antigüidade pelas atitudes ambíguas e práticas condenáveis, diante da impossibilidade de conciliar as leis, as convenções morais com as exigências de uma vida segundo a natureza. O núcleo do cinismo antigo reside na "afirmação de si", termo que reveste o sentido de animalidade. $\mathrm{O}$ cinismo moderno perdeu este significado para remeter-se à ausência de significação. Foucault assinala a presença do cinismo na Europa do século XX, mostrando o deslocamento das categorias antigas para o absurdo do mundo atual: individualismo, existência natural e animal, exasperação da existência particular, afirmação de si, singularidade, vida como escândalo, bios como emergência da verdade - estes traços assumem um valor negativo em relação ao perfil positivo do cinismo antigo (cf. Foucault,1983).

Para se entender a emergência do terrorismo no mundo moderno, é preciso realizar os percursos históricos do cinismo, que se deslocou em três vias: 1) o cinismo, enquanto "verdadeira vida", apresenta-se como "escândalo da vida", do bios, cujo traço característico é o despojamento de tudo, marcando no corpo o "cuidado da vida", a prática da vida. O cinismo cristão e antieclesiástico, a Reforma Protestante e a Contra-reforma Católica são manifestações do "escândalo da vida"; 2) o cinismo é encontrado nas práticas políticas: a "verdadeira vida" eclode como "escândalo da verdade". A atividade revolucionária pode apresentar-se como sociedade secreta, organização instituída ou testemunho da vida por ela mesma, dominando a Europa no final do século XIX e início do século $\mathrm{XX}$ - é aqui que se enquadra o terrorismo; 3) ainda como "escândalo da verdade", o cinismo é encontrado na arte, tanto antiga como moderna. A arte moderna é o lugar da ruptura das formas artísticas conservadoras da ordem do dizer-verdadeiro.

A "verdadeira vida", como "escândalo da verdade", foi assinalada pelos antigos gregos como "coragem da verdade" - manifestação da verdade, princípio fundamental da "vida da verdade", referindo-se a um tipo de relacionamento entre um locutor e sua audiência, de tal sorte que o locutor é o sujeito da enunciação. Nesse tipo de enunciação existe coincidência entre crença e verdade, o locutor é sincero ao proferir a verdade, porque ele sabe que o que ele diz é verdadeiro. Nessa "atividade de linguagem", o discurso está circunscrito a uma exata situação social, na qual existe uma diferença de status entre locutor e seus ouvintes. A sinceridade, inerente ao discurso, deve ser temperada pela "coragem" de dizer a verdade a uma platéia que pensa de forma diferente e disso decorre o risco perigoso que a enunciação da verdade traz em seu bojo, dependendo do que é dito e a quem é dito.

O terrorismo apareceu, no final do século XIX e início do século XX (como sociedade secreta) juntamente com o anarquismo europeu e americano, como "jogo" de vida e morte, afirmação da verdadeira vida, 
como escândalo da verdade inaceitável. O terrorismo, enquanto versão moderna do cinismo, descarta do discurso antigo a vinculação que o sujeito guardava com a lei moral e o dever. O terrorismo apropriou-se da Razão Cínica, na qual sujeitos singulares unem-se em torno de um objetivo geral. Seu estudo possibilita analisar os movimentos terroristas, repensar seus conceitos, seus enunciados, verificar a produção da verdade que envolve a questão da subjetividade, para encontrar o suporte que dá sustentação ao pensar cínico no interior do agir terrorista. A manifestação desse tipo de cinismo segue um rumo diferente das outras formas modernas, como grupos de guerrilha, movimentos revolucionários, etc. Analisar o terrorismo pela ótica foucaultiana permite apreender a eclosão do sujeito cínico, que aparece na cena histórica com outras roupagens, em função de novas formações históricas e em contextos que se constroem sobre outros estratos sociais (cf. Wellausen, 1996).

O cinismo, sob a forma terrorista, apropriou-se de novas estratégias e táticas de poder, para aparecer como o avesso da racionalidade, mostrando um dos lados mais brutais de novas relações de poder. $\mathrm{O}$ terrorismo é a manifestação da irracionalidade inscrita no mundo moderno. De um lado, o indivíduo terrorista apresenta características do cinismo antigo: despojamento de tudo, sem casa e bens materiais, sem nome, sem laços afetivos, sem mulher e filhos, homem do mundo sem apego à vida. De outro, sua identidade é definida como o indivíduo que tem uma única missão a cumprir - o propósito de seu grupo é o fim político de suas estratégias -, diferindo do cinismo antigo, para o qual a finalidade era de natureza moral e religiosa.

A presença do cinismo nos atentados de 2001 ao WTC, atribuídos ao grupo Al Qaeda, tem características do cinismo antigo. De um lado, as exposições do bios ao limite, quando dezenove jovens utilizam a vida, "a verdadeira vida" e o corpo como arma guerreira para fazer aparecer a "verdade" em sua nudez obscena. De outro lado, a identidade do grupo se sintetiza na única missão política a cumprir - matar e expulsar todos os americanos e seus aliados, varrer da terra a cultura americana.

\section{Subjetividade e terrorismo}

Para se entender a emergência do sujeito terrorista na cena histórica, é preciso resgatar o conceito de sujeito, em Foucault. Ao recusar uma teoria do sujeito presente na fenomenologia e do existencialismo, Foucault não descarta a supressão radical da categoria sujeito: este perderia apenas o estatuto de figura constituinte de qualquer forma de conhecimento, para subsistir como pura forma, sem identidade. O sujeitoapresentando-se na história do pensamento como categoria múltipla e fragmentada - introduz o diverso como princípio e o acidente como lei, para redefinir-se em relação aos “jogos de verdade”, à ciência, às instituições 
e às práticas normativas. $\mathrm{O}$ projeto de Foucault poderia ser descritocomo a análise das relações entre as formas de refletividade - relação de si a si - e, portanto, as relações entre essas formas de refletividade e a produção do discurso da verdade, as formas de racionalidade e os efeitos de conhecimento (cf. Wellausen, 1993).

A partir de 1960, Foucault torna possível um trabalho de investigação liberto dos a priori que dá sentido à história. Ao analisar a realidade da doença mental, reconhece que as condições de possibilidade histórica da doença constituem um dado da civilização, desfazendo a ilusão de que o conceito de doença mental seria o reflexo de um conteúdo real um desvio ou má formação -, interrogando sobre sua constituição histórica, seu saber médico e o campo epistemológico da verdade. As leituras estruturalistas dos próximos quinze anos mostram o sujeito totalmente despossuído de sua autonomia e de sua independência de ação. Pela análise das modalidades de produção e de descontinuidade, especificidade e exterioridade, o pensamento foucaultiano da linguagem, nessa fase, passa pela idéia de que não existe sujeito autônomo da palavra. Em realidade, trata-se de uma palavra controlada de várias maneiras pelas instituições. A problemática da "morte do homem" não deve ser vista como a supressão da categoria sujeito, mas como afirmação de seu conteúdo, como objeto de conhecimento e que pode ser afetado pelas mudanças de relações no interior do dispositivo do saber. Para Foucault, o sujeito é uma figura da modernidade que se afirma enquanto palavra livre e subjetiva, resistindo às determinações exteriores.

O tema da experiência está ligado ao do sujeito, como gesto transgressivo, exercício que confronta o real com a prática da liberdade e que, simultaneamente, respeita e viola essa realidade. O tema da transgressão traz como contraponto o limite do ser do homem, o espaço de uma experiência onde o sujeito que fala, no lugar de se exprimir, vai ao encontro de sua própria finitude e sob cada palavra é enviado à sua própria morte (cf. Wellausen, 1993). Este tema reaparecerá em 1983-1984, como o tema da "coragem do dizer-verdadeiro", como forma de exercício da experiência limite. A modernidade traz em seu bojo a experiência limite do gesto transgressivo, da experiência do impossível, esse impossível mediante o qual se faz a experiência e que, paradoxalmente, a constitui.

Para Foucault, o sujeito não é o lugar de um "excesso de subjetividade" - expressão que poderia subentender a permanência e o caráter ontologicamente primeiro da subjetividade em relação aos dispositivos normativos. Não tem a substância do Espírito hegeliano, não é matriz histórico-marxista, nem é a liberdade sartriana; não tem uma sede, nem brota de um núcleo constituinte; é simplesmente uma forma vazia e cambiante que adere aos conteúdos empíricos, porque é produzido pelas formações históricas. O sujeito, como o poder, necessita do "saber" para se 
atualizar, porque tanto um como outro são nomes. Foucault é nominalista, para explicar o poder e o sujeito. Assim como o poder não tem uma natureza, um centro fixo original - sendo somente permitido perguntar pelo seu exercício -, o sujeito manifesta sua liberdade nas formas concretas de sua experiência, opondo uma liberdade concreta e empírica a qualquer possibilidade de uma liberdade formal ou abstrata.

Foucault entende a subjetividade como o conjunto de condições que possibilita o aparecimento do sujeito singular no interior de um contexto histórico, como forma historicamente determinada pelo movimento incessante de múltiplas transformações. A subjetividade recobre uma liberdade prática (descartando a liberdade formal) formada de atos, intenções ou desejos e escolhas de uma maneira de ser. A liberdade não é uma possibilidade ética entre outras, ela é $a$ possibilidade própria da ética, como produto de um permanente questionamento histórico. A história é feita daquilo que pode ser, do que se pode fazer e das possibilidades de vida. A ética foucaultiana não vislumbra um ideal, uma alternativa a partir da qual se possa pensar um mundo melhor. Ele retoma a idéia de uma ética sem ideal, onde as pessoas lutam em situações concretas, sem que suas lutas sejam idealistas. A ética sem ideal tem como diretriz a prática do dizer-verdadeiro, implicando uma atitude crítica a tudo que nos cerca e um desafio a todo fenômeno de dominação.

O sujeito terrorista aparece, num dado momento histórico, como forma consistente, expressando-se no novo cenário deixado vazio pela queda da União Soviética. Novas estratégias e novas táticas são inventadas a partir dos anos 1980, endereçadas ao inimigo. E uma vez instalados na história, "os terroristas, cujo estatuto social depende unicamente do fato de ser terrorista, não podem ser forçados a abandonar esta forma de violência política, porque perderiam sua razão de ser. Ora a elevação do estatuto social e da 'dignidade' proveniente do fato de ser membro de uma rede terrorista é uma das razões principais pelas quais é possível o recrutamento de voluntários que não hesitarão, eventualmente, em matar e morrer, pois a morte fornece a um terrorista um estatuto inegável - ser mártir" (Florent Blanc, 2001, p. 210).

\section{Atentado e autoria}

No terrorismo, o dizer-verdadeiro é a coincidência entre agir e dizer, é a coerência entre o atentado e a enunciação da autoria. É o ato corajoso do dizer-verdadeiro que utiliza a morte de outrem como instrumento e estratégia de poder, não temendo a própria morte no ato da assunção da autoria; é liberdade que excede, é gesto que transgride todos os limites, é poder que toca e funda a finitude humana (cf. Wellausen, 1993).

A liberdade, veiculada no atentado e na autoria do ato terro- 
rista, necessita de dois a priori - a visibilidade e a enunciabilidade -, no interior de intensas relações de poder. A visibilidade, sendo o ato de escolher um ponto qualquer no espaço social para a consumação do atentado, é a prática do panoptismo como condição de possibilidade do atentado terrorista. A enunciabilidade é a declaração da autoria do crime praticado. Poderes localizados imbricam-se num jogo imanente, onde as estratégias surpreendem pelo inesperado. O terrorismo possui sua lógica interna à ação e ao pensamento.

Alguns exemplos mostram a ação pontual e fragmentada de atentados: 1) em 1995, a seita japonesa Aum Shinrikyo (Ensinamento da Verdade) matou 12 pessoas e mandou outras 5.000 pessoas para o hospital como consequiência de um ataque com gás Sarin no metrô de Tóquio (visibilidade) - seu guru, Shoko Asahara, assumiu a autoria do atentado um ano mais tarde (enunciabilidade); 2) também no mesmo ano, uma bomba explodiu diante da estação de metrô Maison Blanche em Paris (visibilidade). Anteriormente, num bairro de mesmo nome na Grande Lion (sul da França), foi morto o terrorista Khaled Kelkal. O atentado em Paris foi reivindicado pelo Grupo Islâmico Armado (GIA) por meio de uma ligação telefônica para uma rádio parisiense (enunciabilidade); 3) em abril de 1995, Timothy McVeigh, um americano ex-combatente da Guerra do Golfo, é o autor (enunciabilidade) da explosão de um prédio federal em Oklahoma nos Estados Unidos (visibilidade), matando 168 pessoas e ferindo mais de 600 . Foi condenado à morte pela corte americana e executado; 4) em 11 de setembro de 2001, os atentados contra as torres gêmeas do WTC (visibilidade), praticados por dezenove terroristas árabes do grupo Al Qaeda, matando quase 3.000 pessoas, é expressão do djhiad decretado por Osama Bin Laden (enunciabilidade), que assumiu a autoria dos atentados de 2001 (cf. D'Ávila, 2002). Antes de 11 de setembro, em 1999, ele declarou ao jornal Le Monde: "Se a incitação ao djihad (guerra santa) contra os Judeus e os Americanos é considerada como crime, que a história me testemunhe como um criminoso. Nosso dever é incitar, e pela graça de Deus, nós o fizemos e certas pessoas têm respondido" (cf. Florent Blanc, 2001).

A análise foucaultiana permite entender o terror, a barbárie e a violência inscrita no mundo atual disseminadas pelo terrorismo, como uma nova forma de oposição a um poder maior, invertendo as clássicas concepções de poder, sujeito e liberdade. O terrorismo é o cinismo pervertido, o espelho quebrado da filosofia, da moral e do pensamento; é a anti-razão em sua grandiosidade.

O terrorismo é fruto de novas relações de poder no mundo atual, do confronto entre poderes dominantes (imperiais) contra dominados. É do interior desse campo de lutas que brotam os gritos de guerra, as palavras-de-ordem, as estratégias de combate que surpreenderão o mundo! Pelo ineditismo de suas ações, é difícil erradicar o terrorismo, tam- 
bém porque ele habita o interior da própria sociedade. As forças de controle podem intensificar estratégias antiterror, sem evitar que uma nova ação terrorista possa eclodir em determinado ponto do planeta; podem localizar e exterminar possíveis agentes pertencentes a organizações, mas não podem prever e impedir quando vai acontecer o próximo atentado, uma vez que não existe defesa tecnológica contra esse tipo de ataque. Nesta tensão presente no interior de intensas relações de poder, o terrorismo coexiste na nova ordem mundial, refletindo uma imagem do mundo e um sintoma de seus males. "O terror vindo de cima vai alimentar a fonte de todo terror vindo de baixo" (Amis, 2001, p. 1), num puro jogo de forças, de ação e reação. O terrorismo é a outra face da violência, perfeitamente coerente com a irracionalidade do mundo atual, aliás, é a única saída que os oprimidos e miseráveis dispõem para o exercício de sua liberdade suicida. E após 11 de setembro de 2001, os EUA se perguntam: "como se proteger de pessoas que estão dispostas a morrer por seus objetivos? O terrorismo suicida é uma arma exclusiva da qual nenhuma potência militar pode dar cabo, e que alcançou a maioridade" (cf. Fisk, 2001, p. 19). "Assim, é preciso dizer, existem poucas chances para que essa forma de violência seja completamente erradicada da cena internacional" (cf. Florent Blanc, 2001, p. 210).

\section{Os atentados aos Estados Unidos}

Foi o advento do segundo avião sobrevoando a Estátua da Liberdade em baixa altitude o instante definidor do terror revelado. Até esse momento, a América achou que estivesse assistindo a nada mais do que o pior desastre aéreo da história, a partir dele, começou a vislumbrar a fantástica veemência que se armava contra ela. $\mathrm{O}$ plano era capturar quatro aviões de carreira - no espaço de meia hora. Todos os aviões estariam partindo para a Costa Oeste, garantia de que estariam com os tanques cheios de combustível. O primeiro se chocaria com a torre norte; em seguida, com uma pausa de 15 minutos, para dar ao mundo tempo para reunir-se em volta de seus aparelhos de TV; com a atenção do mundo garantida, o segundo avião se chocaria com a torre sul. Enquanto isso, um terceiro avião se chocaria com o Pentágono e um quarto seria arremessado contra Camp Davis (local onde foi assinado o primeiro acordo entre árabes e israelenses), ou, possivelmente, a Casa Branca. Pouco depois, o desmoronar das duas torres assinala uma nova era e uma nova verdade brilha: "América, chegou a hora de descobrires o quão implacavelmente és odiada!" (cf. Amis, 2001). A vulnerabilidade dos EUA, na condição de país mais forte do mundo, não contava com os atentados terroristas, que demonstram terem sido preparados com inteligência.

O esgarçamento do tecido mundial, por conta de interesses ego- 
ístas e da violência política usada por diversos regimes dinásticos corruptos tentando desesperadamente manter o poder, um misto de miséria e ditadura, não deixou outro recurso aos oprimidos senão a violência cega e promessas vagas de salvação futura. "O histórico americano de desconsiderar seletivamente os direitos humanos e políticos dos muçulmanos é apenas uma entre as várias razões que explicam o ressentimento duradouro do mundo muçulmano para com a política externa americana. Primordialmente, é o apoio incondicional político, financeiro e militar que os Estados Unidos dão à ocupação brutal da Palestina por Israel" (cf. Dallal, 2001).

Os atentados de 11 de setembro à maior potência mundial marcam um novo episódio nas relações de forças entre os de "cima" e os de "baixo". Depois da Guerra Fria, a União Soviética deixou de existir como inimigo dos Estados Unidos, que precisaram fabricar um novo inimigo para continuar o jogo maniqueísta e, assim, justificar o terror de Estado desenvolvido pelas políticas administrativas e financeiras americanas. Logo foi apontado o novo inimigo - o fundamentalismo islâmico - portador do mal, e o próprio satã era Osama Bin Laden. Sua ligação com diversos atentados cometidos contra os interesses americanos, no decorrer da última década do século XX, faz dele o homem mais procurado pelos Estados Unidos, o inimigo público $\mathrm{n}^{\circ} 1$, tendo sido sua cabeça colocada a prêmio.

E o mundo perguntou, após 11 de setembro de 2001, quais as razões que levaram um jovem homem saudita muito rico a se lançar numa guerra em escala planetária. Causas pessoais? Ou seriam causas mais gerais relacionadas à história das civilizações ocidental e muçulmana? Em que medida Bin Laden e sua rede terrorista podem representar a causa muçulmana em seu conjunto? Em que sentido o apelo ao djihad (guerra santa) implica um esforço de si sobre si, numa estilística de vida, questão ética, ou na defesa dos direitos de Deus?

A resposta compreende duas saídas: por um lado, o cinismo moderno presente nesses terroristas e em todos os outros advindos das camadas de "baixo" se expressa pelo bios exposto ao limite, pelo desprendimento de si, liberdade que excede como estilística de vida, escolha de um modo de vida cínico que não tem medo de perder a vida (é o modo pelo qual o terrorista torna-se mártir como os primeiros cristãos nas arenas romanas), é liberdade suicida; por outro lado, existe um ideal maior, um universal que dá sentido ao ato de matar inimigos e a si mesmo e que é de natureza política. Para os terroristas islâmicos, o objetivo político a ser atingido é a expulsão dos "infiéis" dos territórios palestinos - americanos, israelenses e seus aliados, não só por serem infiéis, mas antes por serem invasores e dominadores. Se a violência é o efeito de uma força sobre qualquer coisa, objeto ou ser, então a entidade terrorista é fruto de intensas relações de poder produzidas historicamente por forças de do- 
minação política. Os atentados aos Estados Unidos refletem esse regime de distribuição de forças entre os de "cima" - os americanos - e os de "baixo" - os terroristas árabes. O apelo ao djihad encobre, no mesmo gesto, o político (com motivação religiosa) e o ético, numa relação de imanência, em que os dois elementos - política e ética - não podem ser pensados separadamente. A religião é o modo pelo qual os terroristas islâmicos utilizam estratégias terroristas (os atentados), no interior de intensas relações de forças como resposta a uma violência americana anterior. O terrorismo de todas as facções é o novo opositor dos Estados Unidos, à medida que a política americana ampliou seu domínio imperial, dizendo "não" às causas mundiais, na oposição às restrições ao uso de armas por civis e à venda de armamento; na rejeição ao acordo de Kyoto a respeito do aquecimento global (o acordo prejudicaria a economia americana); na retirada da delegação norte-americana da Conferência a respeito do Racismo (a reunião discriminaria Israel, seu aliado); no boicote à criação do Tribunal Penal Internacional (julgamento dos crimes de guerra e contra a humanidade); no projeto escudo espacial (Guerra das Estrelas). "Por mais de trinta anos, os Estados Unidos vêm-se recusando a realizar um esforço verdadeiramente imparcial para encontrar uma solução para os conflitos entre Israel e palestinos, (...) jamais aceitando a responsabilidade de tratar imparcialmente os dois lados presos em uma agonia comum e em uma tragédia mútua, (...) os Estados Unidos estão agora arcando com sua parcela da tragédia no Oriente Médio” (Pfaff, 2001).

A expansão dos Estados Unidos pode ser explicada como uma nova ordem capitalista que se materializa, unindo o poder econômico ao poder político. "Em termos constitucionais, os processos de globalização já não são apenas um fato mas também uma fonte de definições jurídicas que tende a projetar uma configuração única suprapartidária de poder político" (cf. Hardt \& Negri, 2001, p. 27). A supremacia do poder político provoca sentimentos de fúria, desespero e indignação moral, desencadeadores de ações terroristas. Uma nova ontologia da violência se instala na história: o poderio americano expande-se e domina o mundo pelo poder político e econômico (os de "cima") contra o crescimento do islamismo radicalizado - enquanto religião e luta política terrorista (os de "baixo”) - estabelecendo relações de poder assimétricas pela ação pontual de suas estratégias.

\section{O terrorista Osama Bin Laden}

Osama Bin Laden nasceu em 1957, filho de Mohammed Bin Laden, um imigrado do Iêmen que funda um império, graças à amizade do rei Faisal da Arábia Saudita. A fortuna de Mohammed cresce vertiginosamente, tornando sua família uma das mais ricas da. Morre em 1966 deixando 57 filhos, que são escolarizados e educados com os filhos do 
soberano saudita. Osama Bin Laden freqüentou a corte real e, desde cedo, esteve em contato com os meios religiosos. Ele tinha 23 anos quando as tropas soviéticas invadiram o Afeganistão, em 1980. Um ano depois, os americanos o escolheram para liderar a guerra contra os soviéticos. Com a ajuda de recursos da CIA e da família, ele mandou vir ao Paquistão e ao Afeganistão engenheiros para construir túneis, novas estradas, depósitos de munição nas montanhas afegãs, assim como hospitais e a infra-estrutura necessária. Em 1986, ele se autoproclamou chefe de guerra, criou sua própria linha de batalha, e entre seus voluntários figuraram antigos oficiais dos exércitos sírios e egípcios, além de jovens vindos de diversas partes do mundo árabe (Iêmen ou Sudão), outros trabalharam nos ricos Emirados Árabes do Golfo Pérsico (na condição de proletários) e outros vieram de territórios palestinos ocupados. Sua presença carismática nos campos de batalha constituiu um encorajamento suplementar para os combatentes sauditas. Bin Laden participou de cinco das maiores batalhas da guerra, assim como centenas de pequenas operações de guerrilha. Desde o início do djhiad de 1980, mais de 50.000 pessoas tinham recebido treinamento militar. No fim da guerra e antes de deixar o Afeganistão, Bin Laden tomou o cuidado de transformar sua rede de combatentes em uma estrutura terrorista internacional, com o objetivo de instaurar um Estado islâmico nos Estados laicos (cf. Florent Blanc, 2001).

O grupo Al Qaeda foi criado em 1988, destinado a registrar a passagem de cada pessoa que teria transitado por um dos pontos do Paquistão ou do Afeganistão (por isso o nome "a Base"), servindo de suporte para o recrutamento de combatentes nos diferentes países árabes (Egito, Arábia Saudita, Paquistão). Bin Laden fez várias alianças com outros grupos terroristas - o grupo islâmico Al-Jihad do Egito, dirigido pelo xeque Omar Abdel Rahman, o National Islamic Front (NIF) e o Hezbollah -, para formar um grupo compacto e unido diante do inimigo comum - o Ocidente e particularmente os Estados Unidos.

Em 1979, desde o início do djihad afegão, Bin Laden decidiu financiar outros grupos islamitas que participavam dos mesmos ideais: o Gama'a al Islamiya (responsável pelo assassinato do presidente egípcio Sadate em 1981). Em fevereiro de 1998, Bin Laden encontrou-se com quatro dos principais líderes islamitas: Ayman Zawahiri chefe do grupo egípcio Al-Jihad; Abdu Salem Muhammad chefe islâmico radical; Fadi Errahmanne Khalil, emir do movimento paquistanês radical; o islamita egípcio exilado Abu Yassir Ahmed Taha. Juntos criaram o Front International do djihad islâmico cujo objetivo era combater os judeus de Israel e seus aliados. Bin Laden também esteve ligado aos Grupos Islâmicos Armados (GIA) da Argélia, nas Filipinas, no Oriente Médio, na África do norte e em Nova Iorque. Além do financiamento de Bin Laden, o djihad islâmico se manteve graças ao tráfico de drogas (a partir do "triângulo de ouro" formado pelo Paquistão, Índia e Afeganistão) e dos 
petrodólares. Na lógica de Bin Laden, os atentados são uma resposta às injustiças praticadas, legitimando o direito de defesa. Na lógica de Bin Laden, os atentados contra os EUA são uma resposta às injustiças praticadas, legitimando o direito de defesa.

Os atentados terroristas não expressam somente a ação de pequenos grupos, mas uma estrutura em escala mundial, onde intensas relações de poder passam tanto pelos dominados como pelos dominantes. $\mathrm{Na}$ rede do poder, a resistência é constitutiva e nunca se encontra em relação de exterioridade; as resistências são o reverso da moeda, o "outro" mesmo nas relações de poder, inscrevendo-se nessas relações como interlocutor irredutível - as relações de poder e os pontos de resistência formam uma tensão permanente no interior do tecido social, podendo dar margem a uma revolução ou ao terrorismo. Assim, "as relações de poder não se encontram em posição de exterioridade com outros tipos de relações (processos econômicos, relações de conhecimentos, relações sexuais), mas lhes são imanentes; são os efeitos imediatos das partilhas, desigualdade e desequilíbrios que se produzem nas mesmas e, reciprocamente, são as condições internas das diferenciações; as relações de poder possuem um papel diretamente produtor (...) as correlações de forças múltiplas que se formam e atuam nos aparelhos de produção e servem de suporte a amplos efeitos de clivagem que atravessam o conjunto do corpo social. Estes formam uma linha de força geral que atravessa os afrontamentos locais e os liga entre si" (cf. Foucault, 1988, p. 90). O poder que vem "de baixo" é expressivo das relações de forças múltiplas que se formam e atuam no interior do tecido social, como contraponto às grandes dominações hegemônicas. Os atos terroristas de 11 de setembro pegaram os EUA desprevenidos e os serviços de informação do mundo inteiro não estavam preparados para enfrentar.

No entanto, após os atentados ao WTC em 2001, a ação de Washington contra Bin Laden e seus partidários foi uma resposta militar, brusca e violenta, quando o presidente Bush mandou invadir o Afeganistão, massacrando as populações árabes miseráveis e, ao mesmo tempo, oferecendo apoio bélico e econômico para que Israel pudesse invadir os territórios palestinos. O terrorismo utiliza táticas e estratégias no interior de intensas relações de poder. O discurso maniqueísta contrapõe o Bem ao Mal e são freqüentes as mútuas acusações, entre o presidente Bush e o terrorista Osama Bin Laden, para justificar as estratégias guerreiras, desconhecendo ambos os conceitos de justiça, respeito à vida, porque o Outro é o diferente a ser destruído. E o maior medo dos Estados Unidos é a ameaça de atentados atômicos. A partir de 11 de setembro de 2001, o terrorismo se afirma como presença ontologicamente persistente, ameaçadora e difusa, ocultando-se na cena histórica e agindo pela surpresa e ineditismo. Dentro dessa nova configuração da geopolítica mundial, o confronto entre o império americano e os terroristas das menores cama- 
das sociais é um fato inevitável e irreversível. O crescimento americano traz prognósticos futuros muito sombrios para o mundo. Segundo Celso Furtado, "a hegemonia econômica e a liderança política americanas podem reiniciar uma nova Guerra Fria. Será uma guerra contra os movimentos sociais indefinidos, contra os países marginalizados, naqueles em que pode se desenvolver esse tipo de fermento perverso que criou o que está por trás desse atentados (WTC). O terrorismo generalizado desencadeará o endurecimento americano e levará a uma confrontação de outro gênero, não mais como guerra mundial, mas de marginalização perversa dos países do Terceiro Mundo (América Latina, África, etc)" (cf. Flamínio Peres, 2001, p. 18).

Não demorou muito para surgir um sentimento antiamericano: "depois de conquistar amplo consenso por pouco tempo durante a operação afegã, o retorno aberto e descarado dos EUA ao unilateralismo vem provocando revolta até mesmo entre seus aliados tradicionais" (Rushdie, 2002, p. 9). Os seguidores de Bush vêm errando feio em todas as principais zonas de crise do mundo; a "guerra contra o terror" é empregada como cortina de fumaça que oculta a condução de vendetas. Se Osama Bin Laden e Saddam Hussein são terroristas que importam aos EUA, outros terroristas fanáticos (hindus) e assassinos (canadenses) não estão na lista do Mal. Hoje, no auge da disputa em torno da estratégia a ser empregada no Iraque, o sul da Ásia virou problema secundário. É no Iraque que o presidente Bush pode estar prestes a cometer seu maior erro e soltar a praga de antiamericanismo. Se tal acontecer, o resultado pode acabar sendo a criação da força islâmica unida (que era o sonho de Bin Laden); a Arábia Saudita pode expulsar as forças americanas de seu solo (satisfazendo a uma das principais exigências de Bin Laden). O Irã que há pouco tempo travava uma guerra brutal contra o Iraque, com certeza vai apoiar o inimigo e entrar na guerra ao lado dele. O mundo árabe seria radicalizado e desestabilizado. Que virada desastrosa da fortuna seria se a temida guerra santa islâmica (o djhiad) fosse iniciada não pela quadrilha de Al Qaeda, mas pelo presidente americano! (cf. Rushdie, 2002).

Recebido para publicação em setembro/2002

WELLAUSEN, Saly da Silva. Terrorism and the attacks of September 11th. Tempo Social, Rev. Sociol. USP, S. Paulo, 14(2): 83-112, October 2002. 
WELLAUSEN, Saly da Silva. Terrorismo e os atentados de 11 de setembro. Tempo Social; Rev. Sociol. USP, S. Paulo, 14(2): 83112, outubro de 2002.

ABSTRACT: The phenomenon of the world fragmentation produced a new order in the relations of power, establishing a new tension between ones of "top" against the ones of "low", creating a vertical line in the old geopolitics axis east/ west of the Cold War. The elements that generate the oppressed identities aim at an affirmation to a way of being, constituting the ontological character of the collective personality. The objective of this work is to consider the theoretical reasons that feed the thought and the terrorist action, its strategies and discursive tactics. An ontology of the violence emerges from the interior of the foucaulians concepts - microphysics, biopower, subject, freedom, games of truth, cynicism. In the new world-wide order, the terrorism while punctual action - threatening and diffuse presence, acting by surprise, disseminating fear and destruction is the opposition to the dominant power, that can also be terrorism of State.

\section{REFERÊNCIAS BIBLOGRÁFICAS}

Amis, Martin. (2001) Medo e repulsa. Folha de S. Paulo. Caderno Especial. São Paulo, 23/09, p. 1-2.

Blanc, Florent. (2001) Ben Laden et l'Amerique. Paris, Bayard.

Dadoun, Roger. (1993) La violence. Paris, Hatier.

Dallal, Ahmad. (2001) Só democracia e riqueza derrotam os radicais do Islã. Veja. São Paulo, Abril, 1732, 26/12, p. 84-87.

D’Ávila, Sérgio. (2002) Ninguém sabe quantos morreram. Folha de S. Paulo. Caderno Especial, 08/09, p. 1.

FISK, Robert. (2001) O terrorista suicida veio para ficar. Folha de S. Paulo. Caderno Especial. São Paulo, 14/09, p. 19.

Flamínio Peres, Marcos. (2001) Furtado vê "nova Guerra Fria”. Folha de S. Paulo. Caderno Especial. São Paulo, 14/09, p. 18.

Foucault, Michel. (1983) The Problematisation of Parrhesia. Notes to the Seminar given by Foucault at the University of California at Berkeley, ed. by J. Pearson (Archives Foucault).

. (1988) A vontade de saber. $7^{\text {a }}$ edição. Rio de Janeiro, Graal.

. (1991a) Faire vivre et laisser mourir: la naissance du racisme. Les Temps Modernes, Paris, 525, février.

(1991b) Le courage de la vérité. Fin du cours du 8/2/1984 et début du cours du 15/02/1984 au Collège de France, 1694/1991. 1 bde.Magn. En cassette, C 69(3). Paris, Bibliothèque du Salchoir.

(1991c) Vigiar e punir. $8^{\mathrm{a}}$ edição. Petrópolis, Vozes.

Hardt, Michael \& Negri, Antonio. (2001) Império. Rio de Janeiro, Record.

violence, terrorism, power, biopower, cynicism, racism,

September $11^{\text {th }}, 2001$. 
IANNI, Octavio. (1996) A racialização do mundo. Tempo Social; Revista de Sociologia, USP; São Paulo, 8(1): 1-23, maio.

NATALI, João Batista. (2001) Terror entrou para a política com a Revolução Francesa. Folha de S.Paulo, São Paulo, 30/09, p. A21.

Pfaff, William. (2001) Três lições para os Estados Unidos. Folha de S. Paulo. Caderno Especial. São Paulo, 14/09, p. 4

RushdiE, Salman. (2002) Antiamericanismo exige olhar sóbrio dos EUA. Folha de S.Paulo. Caderno Especial. São Paulo, 01/09, p. 9.

MAXwELl, Keneth. (2002) Novo terrorismo é incontrolável. Entrevista a Maurício Santana Dias. Folha de S. Paulo. Caderno Especial. São Paulo, 13/09, p. 19.

Santos, J. F. (1994) O que é Pós-Moderno. São Paulo, Brasiliense.

TAHERI, Amir. (2001) O ódio dos muçulmanos ao ocidente é cultivado por governos e imprensa. Veja. São Paulo, Ed. Abril, 1732, 26/ 12 , p. $70-73$.

Wellausen, Saly. (1996) Michel Foucault: parrhesia e cinismo. Tempo Social, SãoPaulo, 8(1): 113-125, maio.

. (1993) A liberdade no pensamento de Michel Foucault. São Paulo, 191p. Tese (Doutorado). Faculdade de Filosofia, Letras e Ciências Humanas da Universidade de São Paulo.

World Media. (1990) A nova desordem mundial 1, 2, 3. Folha de S. Paulo. São Paulo, 19-20-21/12. 